Jurnal Office: Jurnal Pemikiran Ilmiah dan Pendidikan Administrasi Perkantoran

Vol. 6, No. 2, July-December 2020, Page 117-122

Homepage: http://ojs.unm.ac.id/jo

\title{
Democracy and The Nature Of African States: Towards an Institutional Reform For African Development
}

\author{
GABRIEL ASUQUO \\ College of social and Management Sciences Achievers University \\ Email: gabrielmarcel76@yahoo.com
}

\begin{abstract}
Democracy is a political culture that seeks to promote majority participation in the process and art of governance, with the aim of developing a society; based on the principles of equality, freedom and social justice. This implies that democracy must operate within the confines of a State structure, which means there must be a State before we can talk about the enthronement of democratic culture and institutions. Thus, this paper examined the nature of African States and discovered that Africans are operating a dislocated state structure that is at far variant, with Universal Characteristics of a State. This is so because the contemporary African States are part of African colonial legacy and the failure of African peoples to evolve after 50 years of colonialism are responsible for this state of affairs. Hence, the paper defended the thesis that until Africans reform their institutional arrangement, to reflect the Universal Characteristics of a State Structure, democracy in Africa will not deepen, and development will keep eluding the continent and her people. This reform agenda which the paper is proposing is premised on traditional African values and spirituality. The paper employs the method of critical analysis.
\end{abstract}

Keywords: democracy, State, Institution, development, Africa, reform

\section{INTRODUCTION}

This paper takes a critical look at democracy and the nature of African states; and argues for structural reforms of postcolonial African states that will reflect the diverse nature of the African People. Also, the paper argues the thesis that Africans need to have effective States structures that reflect the Universal Characteristics of a State, before talking about the deepening of democracy in Africa. This is born out of the fact that democracy thrives in an effective state structure that is based on depersonalized rules, freedom and justice (Becker \& Raveloson, 2008; Mestquita \& Downs, 2005; Andersen \& Jensen, 2019; Qiao, Ding, \& Liu, 2019).

Globally, democracy is now being viewed as the only option open for human sociopolitical development and as the only form of governance that can engender global peace and security, (Rose, 2019). This assumption is predicated on the fact that democratic regimes cannot engage in violent conflict with one another without taking recourse to the wishes and decisions of the people through their representatives. It is based on the above, that United States of America (USA) and its allies are preaching the gospel of liberal democracy to new states, most especially postcolonial African States, which they believe can make Africans be to 'free' in order to be developed. Thus, the rush for the democratization of Africa, as soon as the decolonization project ended in 1994. However, when we look critically at Africa today, we will see what free market or liberal democracy without an effective state structure, is doing to the peace and stability of Africa. How does all these play-out in Africa?

(Chua, 2004, p. 6-7) opined that markets concentrate spectacular wealth in the hand of the market-dominant minority, while democracy increases the political power of the impoverished majority. Hence, the pursuit of free market democracy becomes an engine of potentially catastrophic ethnonationalism which inspires vote-seeking politicians to flame resentment against the wealthy marketminority, from the frustrated "indigenous" majority, who are made to believe that their impoverishment is 


\section{8| Jurnal Office: Jurnal Pemikiran Ilmiah dan Pendidikan Administrasi Perkantoran}

Vol. 6, No. 2, July-December 2020, Page 117-122

caused by the wealthy ethnic minority. We see how this play out in Sierra Leone, Zimbabwe, South Africa, Rwanda, and Kenyan, etc. Although, what Chua failed to add is that, it is not the free market or liberal democracy that is causing ethnic hatred and political instability in Africa but the nature of African States. This is what this paper seeks to interrogate with a view of finding out workable arrangements for African development.

In addition, democracy is a system of government (Becker \& Raveloson, 2008) and not a theory for the organization of a State. In other words, there cannot be a democratic regime without necessarily talking about the existence and functionality of a State. A State must exist and made to be functional before we ask, what kind of government should administer the State? The State comes first before democracy (D'arcy \& Nistotskaya, 2015). This is where the postcolonial African States failed and continue to fail. The post-colonial African States is a deliberate creation of African former colonial masters, which was created as colonies for the exploitation of resources, not a place to be developed, so as to make the indigenous people live the good life. It was meant to enrich the colonial metropolises at the detriment of the indigenous people (Rodney, 1972; Duke \& Osim 2020; Edor 2020).

Thus, at independence African elites who took over from the colonial masters never thought it wise to rebuild the foundation of the independent States, on the basis of the wishes, ends, and aspirations of the people. They just continued where the colonial masters stop, as such, due to their mismanagement of the existential tensions that arise in postcolonial African society their rule were judged worse than the colonial masters. This failure to rethink and undo the foundation of postcolonial African State is the prime cause of the failure of all democratic experiments and developmental policies in Africa.

Therefore, to address the above, the paper shall be divided into four sections. Section one will discuss the concept and approaches of democracy, while section two will discuss the concept and characteristics of the State. Section three will do an x-ray of the nature of African States, while section four will discuss the need for reform of the African States that will encompass the nature and conditions of the African people. We end the paper with a conclusion.

\section{METHOD}

This research uses critical analysis method. The critical analysis research method is an example of the application of qualitative methods that are carried out in an explanative manner. The analysis in this study was carried out by interpreting or interpreting various existing sources. Therefore, subjectivity cannot be avoided in this study. However, the subjectivity is minimized with the results of linguistic analysis as evidence.

\section{DISCUSSION}

\section{The Nature Of African States}

Historically, what we know as the modern African States were created by European colonial powers most especially, Britain, France, Spain, Portugal, German and Italy. Although, the enduring colonial powers with large colonies were Britain and France. Africa as a continent was partitioned by Colonial powers in Berlin during what is regarded as the Berlin Conference of 1884/5. It was in this conference that Africa was wholesomely shared among colonial masters, without taking in considerations local conditions and internal political dynamics. The consequence of this singular action by European 
powers redirected the destiny of the African people. Sworn enemies were grouped together in a single colony, an ethnic group were divided along different colonies and 'owned' by different masters (Harris, 1987, p. 166-167). Therefore, after independence African nationalists maintain this structure and its underlining philosophies.

From the above, it is very clear that the African States do not organically emerge from African society just as we see in the history of other States in the international system. Also, African States were not created to advance the course of Africans but to perpetuate the interest of European Powers. If this is the case, it then means that the African States was not set up in the first place, for African development rather, it was an arena for exploitation in order to develop the European Metropolis. This is the African tragedy and it is fanning toxic politics in the African States that is undermining development and authentic progress.

Furthermore, just as we stated in the previous section that the Universal characteristics of modern States are: Sovereignty, population, government, and territory. Using these as a yardstick, the question that resonates is, what then is the nature of the Sovereignty of African States? The question of the sovereignty of African States lies in where and who has vested the powers of the States. Should it be in precolonial leadership and traditional institutions or the postcolonial institutions? This question is at the heart of the debate of the legitimacy of the modern African States. Some Africans still see the postcolonial states as a Whiteman property, as such, it is not connected to them. This is why you hear government workers most especially in Nigeria, saying "is government work your father business?" This implies that the State is not an extension of them but a foreign occupational force. This is why politicians can misappropriate State resources but they cannot do that with their ethnic or tribal resources. These actions questioned the legitimacy of the African States as an entity that can make binding laws for the entire society. In fact, some African States only operate in urban centers while some sub-state groups operate in rural areas.

More so, we need to ask what the nature of the population of African states is. Although, there is no State in the world that has a homogenous population, however, there is something that binds the entire state towards a collective purpose, which may be called an ideology or national values. This is what is critically but lacking in many African States - a common ideology or national values. Historically, we know that the modern African States are deliberate colonial creation without taking local factors into considerations which consequently, is fanning ethnicity, tribalism, nepotism, clannish agenda, neopatrimonialism among African States population. The population of some of African States are divided not only on ethnic line but on a religious line, with severe consequences on the stability and security of the State. This divided population without a national consensus is what caused the secession of South Sudan from Sudan. It is also causing secession agitations and ethnic exclusion in the politics of some African States. Places, where these tensions are not properly managed, has led to civil wars, genocide, massacre, and ethnic cleansings.

Also, the nature of governance in Africa call for serious concerns. This is because according to (Akude, 2007, p. 4), governance is the "manner in which power is exercised in the management of a country's economic and social resources for development". The way which the government of the State operates has serious consequences on the legitimacy of the State. (Akude, 2007) argued that the purpose of government is to deliver the political good of the state which security of life and property and others are: open participation, welfare (healthcare and education, social security, etc.), and provision of infrastructure, etc. If the government fails in delivering this political good for the state, it weakens the legitimacy of the state and the spirit of Patriotism, which is needed to foster the development of the State. Due to ineptitude leadership, foreign negative influences, poverty, and abuse of power on the part of the government, many African States are failing consistently in this regard. This has created a governance 


\section{0| Jurnal Office: Jurnal Pemikiran Ilmiah dan Pendidikan Administrasi Perkantoran}

Vol. 6, No. 2, July-December 2020, Page 117-122

deficit which some non-state actors are capitalizing on, to perpetuate their agenda that are threatening the peace and stability of some African States.

Also, the territorial integrity of many African States is still under contention by state and nonstate actors all scrambling for the right of ownership. Historically, modern African states were former colonies, which were created by the colonial powers without taking into consideration local conditions, politics, and histories. In other words, Africans were not part of that conference that defined their States. The implication is that enemies were made to stay together and brothers were divided between colonies that metamorphosed into States. Therefore, the territory that defined the African States are colonial and artificial, and as such, it has given rise to non-state actors who are laying claims to some areas within some African states. These non-states actors can be ethnic militia, militant groups, rebels, insurgents or terrorists who are laying claim to some parts of the territory of some modern African States.

The implication of the above state of affairs, the modern African States are dislocated States, in the sense that, they do not reflect in a holistic manner, the universal characteristic of a State. A dislocated state is a state that lack legitimacy and mass support in it policies and actions (Nurudeen, 2009). A dislocated State is a State that has weak bureaucratic and policing institutions for law enforcement and cohesion (Fukuyama, 2013). A dislocated State is a state that is characterize by corruption and abuse of power on the part of those who run the affairs of the government (Nurudeen, 2009). Furthermore, a dislocated state is a State that is not in alignment with the society that created it in terms of ideology, destiny and purpose (Pisani, 2010). Finally, a dislocated states is a state that has personalized leadership culture that vested powers on persons rather than on institutions that outlived the person (Olowu, 1994). Therefore, if the above is a true reflection of the African situation, it calls for a reform that will enthrone the State as an institution, before we talk about how to run the state which is the hallmark of democracy.

\section{Toward an Institutional Reform for Development in Africa}

According to (Fukuyama, 2013), there is a relationship between the quality of a State and the success of democracy within that state. Democracy no doubt is an intrinsic value but the nature of state bureaucracies and structures will determine the limit of mass participation in the process and art of governance. While, we commend the west for trying to entrench the liberal democratic culture in Africa, especially in the 1980 s to date, we need to emphasize that democracy without high-quality state that reflects the character of a republic or a constitutional monarchy will not foster the political or socioeconomic development that the west envisioned for Africa. Our contention is that Africans must evolve their own state structures that reflect elements of traditionalism and modernity in the context of globalization and other realities that confronts the continent today.

We need to engage the current structure, borders, and boundaries of Africa. This is because some of the African borders are too artificial, which divide brothers along independent or sovereign states, which in the long run is posing a security threat to the existing states. Africans in this century must undo the Berlin Conference resolution that partitioned Africans along state structure that does not reflect their histories, culture, and destiny. If Africans do not undo Berlin Conference resolution, the quest for selfdetermination of a people within an existing state will continue, and in the process of time, some will be violent and brutal which will become a global menace soon. The African States are sitting on gunpowder that will explode soon and the threat is overwhelming. We can see the early warning signs from the rise of secession groups, Boko Haram, Al-Shabab, Rebel groups, Militants, Ethnic Militia and others. Africans must and need to undo the Berlin Conference resolution. How can it be done?

The African Union should as a matter of urgency should commission Ethnographers, Historians, Philosophers, Political Scientists and Geographers to carry out studies that will aid the Union, in making 
informed decisions on the restructuring of borders and boundaries of existing African states, in a way that each state is a reflection of people who historically are brothers and allies, not like what we are having now. This call is similar to what Ottoman Bismarck and the European Powers did that resulted in the conditions Africa is facing today. Although, we are aware that, this is not an easy task due to vested interests on the part of African leaders and their oversea counterparts. This is why Africa needs a new generation of leaders, who can reimagine new paths for African sociopolitical cum economic prosperity and development.

However, we commend the single African International Passport or Regional Passports, which was designed to aid the free movement of Africans across Africa. We need to add that, the African Union should address the question of who really owns the modern African States. Is it the African peoples or their former colonial masters? Until Africans answer this question, the problem of neo-colonialism, neopatrimonialism, and clientele-patron relationship will keep undermining the quality of African States; and democracy will remain a window-show for the perpetuation of the wealthy class, who can win elections and rule the State without any authentic development.

Furthermore, another option that is open for Africans is the need to choose between traditional institutions with its attendant principles of social ordering and social living and current colonial institutions. In other words, Africans should choose what form should their States takes. Should it be monarchical States or republican States? If it is monarchical states it then implies that all the ancient kingdoms of precolonial Africa, should be the basis of African restructuring. However, if the African States choose to be republican, then, the current structure should be maintained with minimal restructuring in terms of culture and current values. This entails that Africans must be cosmopolitan and urbanized which is the hallmark of modernity. Modernity is what Africa needs now, as such, Africans must work towards the urban or metropolitan pattern of social organization. The implication is that Africans must embrace fully the values of western individualism and its attendant institutional arrangements for social ordering and social living. This means that Africans must be ready to westernize in thoughts, spirit and social outlook. These are the choices that are open for Africans as they move to the next fifty years of independence.

\section{CONCLUSION}

The paper has highlighted the meaning and features of democracy as a political value that can foster good governance but not a good state. The state must exist first as a Juristic personality that commands total respect and legitimacy from the total population. If this is lacking the state is dislocated and in the process of collapsing, just as we find in history. Hence, as we examine the nature of modern African States we discover that some of them are dislocated States, which entails that they do not reflect the Universal Characteristic of modern State structure. There are many factors that are responsible for this state of affairs but the principal one is colonialism and the Berlin Conference Resolution of 1884/5 that partitioned Africans along colonies which metamorphosed into independent States. Therefore, the institutional reform of African states must start by jettisoning the resolution of the Berlin Conference through the restructuring of the existing border and boundary before any other thing.

\section{REFERENCE}

Andersen, T. B., \& Jensen, P. S. (2019). Preaching democracy: The second Vatican council and the third wave. Journal of Comparative Economics, 47(1), 525-540. 


\section{2 | Jurnal Office: Jurnal Pemikiran Ilmiah dan Pendidikan Administrasi Perkantoran}

Vol. 6, No. 2, July-December 2020, Page 117-122

Akude E. J (2007). The failure and Collapse of The African State: on The Example of Nigeria. German: FRIDE Madrid.

Becker P. and Raveloson J A.A (2008). What is Democracy? Andriakamelo R. A (Trans.). Trier: KMFCnoe \& Nova Stella.

Chua A (2004). World on Fire - How Exporting Free Market Democracy Breeds Ethnic Hatred and Global Instability. New York: Anchor Books

D'archy M and Nistotskaya M (2015). State First, then Democracy: Using Cadastral Records to Explain Governmental Performance. QoG Working Paper Series. Department of Political Science, University of Gothenburg.

Duke, E. O., \& Osim, S. (2020). From festival to social communion: a Nigerian experience. Przestrzeń Społeczna 19 (1), 53-70.

Edor, E. J. (2020). A Jurisprudential and Socio-Cultural Reconsideration of the Rape Phenonmenon. Jurnal Sosialisasi: Jurnal Hasil Pemikiran, Penelitian dan Pengembangan Keilmuan Sosiologi Pendidikan. (2), 50-57.

Fukuyama F (2013). Democracy and the Quality of the State. In Journal of Democracy. 24 (4), 5-16

Harris E.J (1987). Africans and their History. New York: Penguin Group

Mestquita, B. B., \& Downs, G. W. (2005). Development and Democracy. Foreign Affairs, 84(5), 77-86.

Nurudeen S. L (2009). Introduction to African Politics. National Open University of Nigeria

Olowu D. (1994). The Nature and Character of African State. (Being a Paper Presented for AAPM $15^{\text {th }}$ Roundtable at Banjul, Gambia, 24-29 January, 1994

Pisani A. (2010). State and Society under South African Rule, in Kenlder C. (Ed), State, Society and Democracy: A Reader in Nambian Politics. Windhoek: Macmillan Education Namibia (Pty) Ltd

Qiao, M., Ding, S., \& Liu, Y. (2019). Fiscal decentralization and government size: The role of democracy. European Journal of Political Economy, 59(1), 316-330.

Rodney W (1972). How Europe Underdeveloped African. London: Bogle-L 'Ouverture Publications

Rose, M. (2019). Hesitant democracy: Equality, inequality and the time of politics. Political Geography, 68(1), 101-109. 